\title{
Lentil Response to Nitrogen Application and Rhizobia Inoculation
}

\section{Authors: Jinwen Huang, Reza Keshavarz- Afshar, and Chengci Chen}

This is an Accepted Manuscript of an article published in Communications in Soil Science and Plant Analysis on November, available online:

http://www.tandfonline.com/10.1080/00103624.2016.1254786.

Huang, Jinwen, Reza Keshavarz Afshar, and Chengci Chen. "Lentil Response to Nitrogen Application and Rhizobia Inoculation." Communications in Soil Science and Plant Analysis 47, no. 21 (November 2016): 2458-2464. DOI: 10.1080/00103624.2016.1254786.

Made available through Montana State University's $\underline{\text { ScholarWorks }}$ scholarworks.montana.edu 


\title{
Lentil Response to Nitrogen Application and Rhizobia Inoculation
}

\author{
Jinwen Huang ${ }^{1}$, Reza Keshavarz Afshar ${ }^{2}$, and Chengci Chen ${ }^{2 *}$ \\ ${ }^{1}$ College of Crop Science, Fujian Agriculture and Forestry University, Fuzhou, China \\ ${ }^{2}$ Eastern Agricultural Research Center, Montana State University, 1501 N. Central Ave., \\ Sidney, Montana, USA
}

Address Correspondence to Chengci Chen: cchen@montana.edu

\section{ABSTRACT}

Lentils (Lens culinaris L.) are an important component of the dryland farming systems in the western USA. Optimum nitrogen $(\mathrm{N})$ management can enhance yield and quality of lentils. We conducted a field (at two locations, one with previous history of lentil and the other one without lentil history) and a greenhouse study to evaluate response of lentil to the application of rhizobium inoculant and starter $\mathrm{N}$ (control, $22 \mathrm{~kg} \mathrm{~N} \mathrm{ha}^{-1}$ in the form of urea [U], $22 \mathrm{~kg} \mathrm{~N}$ $\mathrm{ha}^{-1}$ in the form of slow release or Environmentally Safe Nitrogen [ESN], and $22 \mathrm{~kg} \mathrm{~N} \mathrm{ha}^{-1} \mathrm{U}+$ $22 \mathrm{~kg} \mathrm{~N}$ ha $\left.{ }^{-1} \mathrm{ESN}\right)$. In both, the field and the laboratory studies, lentil yield did not respond positively to the experimental treatments. Lentil average yield was 1216 and $1420 \mathrm{~kg} \mathrm{ha}^{-1}$ at 
the field condition. In this rain-fed systems lentil yield was mainly limited by moisture availability and application of an external $\mathrm{N}$ did not contribute to the yield enhancement. Both of treatments, however, increased protein content. Compared to the control, application of rhizobium plus U and ESN enhanced protein content by about 34\% (from 23.1 to $30.9 \%$ ). Application of U+ESN also considerably increased post-harvest residual nitrate (NO3)-N in the soil, which can be easily leached and create environmental pollution. Briefly, application of U+ESN increase lentil protein content, but more efforts are needed to optimize $\mathrm{N}$ management in lentils in order to reduce the environmental concerns in the shallow soil.

Keywords: Protein; Pulse Crops; Seed inoculation; Slow-release nitrogen; Starter nitrogen.

\section{INTRODUCTION}

Cool season grain legumes, including lentils, are an important component of the dryland farming systems in the western USA. Montana is the principal growing region of lentils in USA with about $38.6 \%$ share in the U.S total lentil production (Montana Agricultural Statistics 2014). The inclusion of grain legumes such as lentils in the cropping system offers numerous economic and agronomic benefits to the growers (Ito et al., 2015; Haque and Lupwayi, 2000; Miller et al., 2002; Chen et al. 2012). Biological nitrogen (N) fixation 
(Herridge et al., 2008), water preservation (Miller et al., 2002), decreased risk of particular cereal diseases (Yunusa and Rashid, 2007), suppressed wheat-competitive weed populations (Buhler et al., 2001), and increased soil microbial activity and biomass (Alvey et al., 2003) are among the important benefits that grain legumes offer to the system.

Similar to other legume crops, lentils are able to attain a part of their $\mathrm{N}$ requirements through symbiotic fixation of atmospheric $\mathrm{N}\left(\mathrm{N}_{2}\right)$, the extent of which highly depends on the environmental conditions (Van Kessel and Hartley 2000). Nevertheless, appropriate N management through application of effective rhizobia inoculants and starter fertilizer can optimize and incentivize grain legume production (Salvagiotti et al. 2008; Huang et al., 2016). The majority of the growers in Montana, use seed or soil applied commercial rhizobia inoculants at the time of lentil seeding whereas no $\mathrm{N}$ fertilizer is usually used. Due to the lag phase between rhizobial root colonization infection and the onset of biological $\mathrm{N}$ fixation (Van Kessel and Hartley 2000), the young lentil plants may require a small amount of external $\mathrm{N}$ to attain a sufficient vegetative growth. On the other hand, inappropriate use of starter $\mathrm{N}$ can interfere with seedling emergence and biological $\mathrm{N}$ fixation. If soil $\mathrm{N}$ is high, legumes preferentially use $\mathrm{N}$ from soil than taking $\mathrm{N}$ from the atmosphere due to a lower energy cost for the crop to take up $\mathrm{N}$ from the soil (Graham and Chatel, 1983).

In our earlier effort, we found that when initial soil $\mathrm{N}$ was low, application of starter $\mathrm{N}$ increased dry pea yield in central Montana (Huang et al., 2016). McKenzie et al. (2001) also 
found that when spring soil to $30 \mathrm{~cm}$ depth has less than $20 \mathrm{~kg} \mathrm{~N} \mathrm{ha}^{-1}$ nitrate nitrogen $\left(\mathrm{NO}_{3}-\mathrm{N}\right)$, application of starter $\mathrm{N}$ fertilizer increased pea yield at $33 \%$ of their trials by an average of $11 \%$. Gan et al. (2005) reported that lentil seed inoculation with rhizobium bacteria increased seed yield by $15 \%$ on silt loam soils and $70 \%$ on the heavy clay soils in the semiarid Canadian prairies. They also found that application of starter $\mathrm{N}\left(15 \mathrm{~kg} \mathrm{ha} \mathrm{h}^{-1}\right)$ increased seed yield by $13 \%$ for lentil grown on the heavy clay, but there was no effect on the silt loam. Little is known about $\mathrm{N}$ management for lentil in rain-fed condition of Montana.

Nitrogen availability especially at late growing stage also plays an important role in protein concentration in seeds of legume crops. It has been shown that insufficient $\mathrm{N}$ availability during grain filling can cause a reduction in grain $\mathrm{N}$ and protein concentration in legume like peas (Holl and Vose 1980). On the other hand, some researchers noticed that high $\mathrm{N}$ availability during grain-filling can stimulate legumes vegetative growth at the expenses of $\mathrm{HI}$ and grain yield (Zakeri and Bueckert, 2015). Therefore, optimal N management can increase the quality (protein content) of the product without sacrificing the yield.

Slow-release nitrogen fertilizers release $\mathrm{N}$ gradually and supply the higher amount of $\mathrm{N}$ at later growth stages. Environmentally safe nitrogen or ESN® $(44 \% \mathrm{~N}$; Agrium Inc., Calgary, Canada) is a polymer coated urea that releases $\mathrm{N}$ slowly. This fertilizer has been applied successfully in production of a diversity of crops. The effect of ESN on grain legumes has received insufficient attention yet. In our previous experiments, we noticed beneficial effect 
of ESN compared to regular urea on pea production (Huang et al., 2016).

In this study, we evaluated the response of lentil plants to commercial rhizobia inoculant and application of starter $\mathrm{N}$ fertilizer (urea vs. ESN) in field and a controlled greenhouse environment. We hypothesized that application of ESN as a starter $\mathrm{N}$ can increase yield and protein content in lentils.

\section{MATERIALS AND METHODS}

Field Study

Field trials were conducted at two sites in central Montana $\left(47^{0} 03^{\prime} \mathrm{N}, 109^{0} 57^{\prime} \mathrm{W} ; 1400 \mathrm{~m}\right.$ elevation) in 2012. The experiments were conducted at the Central Agricultural Research Center (CARC) and at a cooperating grower's farm (SG farm). The CARC site has been planted with lentil in the past, and the SG farm did not have a history of lentil in their cropping systems. Soils in central Montana are shallow in depth and the soil characteristics are presented in Table 1. The soil series at this region is Judith-Danvers and soil type is gravelly clay loams with 0 to 4 percent slopes. Typical profile is gravelly clay loam (0- 66 $\mathrm{cm})$ and extremely gravelly sandy clay loam $(66-152 \mathrm{~cm})$. The soil is well drained and depth to water table is more than $200 \mathrm{~cm}$, with 60 percent maximum calcium carbonate in profile, 
and non-saline to slightly saline $(0.0$ to $4.0 \mathrm{mmhos} / \mathrm{cm})$ (United States Department of Agriculture, Natural Resources $\quad$ Conservation Services, http://websoilsurvey.sc.egov.usda.gov/App/WebSoilSurvey.aspx).

Weather parameters, including cumulative precipitation and average temperature during lentil growing season in 2012 and 2015 are shown in Figure 1. Crops were rain-fed at both locations.

The trials were conducted on a randomized complete block design with four replications. The experiments included four levels of starter $\mathrm{N}$ [i.e., $0 \mathrm{~N}, 22 \mathrm{U}\left(22 \mathrm{~kg} \mathrm{~N} \mathrm{ha}^{-1}\right.$ in the form of urea), $22 \mathrm{ESN}\left(22 \mathrm{~kg} \mathrm{~N} \mathrm{ha}^{-1}\right.$ in the form of ESN), and $\left.22 \mathrm{U}+22 \mathrm{ESN}\right]$ and rhizobia inoculation (with and without rhizobia inoculant). A peat powder inoculant named N-Charge which contains a minimum of 2 x 108 cfu per gram of Rhizobium leguminosarum biovar viceae (INTX Microbials, LLC, Kentland, IN) was used at the labeled rate as rhizobia inoculant in the corresponding treatments. The inoculant was mixed with seed prior to planting.

Lentil seeds (cv. Richlea) were sown on April 2012 using a no-till plot drill at a seeding rate of 128 seed $\mathrm{m}^{-2}$ in $0.30 \mathrm{~m}$ row spacing. Prior to seeding, seeds were pre-treated with fludioxinyl and mefenoxam fungicide (Apron MAXX® ${ }^{\circledR}$ RTU, Syngenta) and thiamethoxam insecticide (Cruiser MAXX® ${ }^{\circledR}$, Syngenta, Basel Switzerland) to control soil-borne diseases and pea leaf weevil infestation.

When plants matured (August), a plot combine was used to harvest the lentil seeds. After 
cleaning, seed weight and moisture content was determined. Grain yields reported herein are adjusted to $13 \%(\mathrm{w} / \mathrm{w})$ moisture content

\section{Greenhouse Study}

The greenhouse study was conducted at the EARC Research and Education Greenhouse of Montana State University in Sidney, Montana from September 2015 to January 2016. The greenhouse condition was set at $16 \mathrm{~h}$ light $/ 8 \mathrm{~h}$ dark, temperature $20 \pm 1{ }^{\circ} \mathrm{C}$ and $55 \pm 5 \%$ relative humidity. Experimental pots $(22 \mathrm{~cm}$ diameter or $7.5 \mathrm{~L}$ ) were filled with five $\mathrm{kg}$ sieved soil sampled from $0-15 \mathrm{~cm}$ depth of a field with the following characteristics: Savage clay loam (fine, smectitic, frigid Vertic Argiustolls); $2.3 \%$ organic matter; $\mathrm{pH}$ of $8.3 ; 6.5 \mathrm{mg} \mathrm{kg} \mathrm{kg}^{-1}$ $\mathrm{NO}_{3}-\mathrm{N} ; 26 \mathrm{mg} \mathrm{kg}^{-1}$ Olsen phosphorous; $22 \mathrm{mg} \mathrm{kg}^{-1}$ sulfate sulfur; and $346 \mathrm{mg} \mathrm{kg}^{-1}$ potassium. Treatments were similar to the field trials (equivalent to the four levels of starter $\mathrm{N}$ treatments in the field study, i.e., $0 \mathrm{~N}, 22 \mathrm{U}\left(22 \mathrm{~kg} \mathrm{~N} \mathrm{ha}^{-1}\right.$ in the form of urea), $22 \mathrm{ESN}\left(22 \mathrm{~kg} \mathrm{~N} \mathrm{ha}^{-1}\right.$ in the form of ESN), and $22 \mathrm{U}+22 \mathrm{ESN}$ ) and rhizobia inoculation (with and without rhizobia inoculant) and arranged as factorial in a randomized complete block design with 12 replicates (the amount of fertilizer used were calculated based on soil weight per unit area). All pots received equal watering throughout the lentil life cycle in order to prevent drought stress.

Cultivar Richlea was also used for the greenhouse study. Seeds were sown on October 1, 
2015. Commercial peat powder rhizobia inoculant named N-Charge (INTX Microbials, LLC, Kentland, IN) was applied to seed prior to planting. Similar to the field experiments, seeds were treated with fludioxinyl and mefenoxam fungicide (Apron MAXX® RTU, Syngenta) and thiamethoxam insecticide (Cruiser MAXX®, Syngenta, Basel, Switzerland) to control soil-borne diseases and pea leaf weevil infestation before sowing.

Twenty five seeds were planted to $3 \mathrm{~cm}$ depth in each pot and uniform watering was given to ensure good germination and establishment. After full establishment, five plants in each pot were removed and 20 seedlings were kept at each pot. At seven-leaf stage, four replications (pots) from each treatment were randomly selected and plants were uprooted, then plant biomass was determined (after drying at $65^{\circ} \mathrm{C}$ ).

At full-bloom stage, another four replicates (pots) from each treatment were selected for destructive sampling. Plant biomass, root and shoot length, and nodule plant ${ }^{-1}$ was determined. Nitrogen concentration in whole plant was also determined by Duma combustion using a Perkin Elmer Series II Nitrogen Analyzer (Frederic 1963) then multiplied by 6.25 to show protein percent.

When plants matured, plant height, number of pod plant $^{-1}$, numbers of grains pod $^{-1}$, average grain weight, and grain yield plant ${ }^{-1}$ were determined. Harvest index (HI) was calculated as the function of grain weight to biomass weight per plant basis. Finally, a sub sample of plant straw and grain was ground and analyzed for protein measurement as described previously. 


\section{Data Analysis}

Data was subject to Analysis of variance (ANOVA) using Proc Mixed of SAS. Means were separated using Fisher's LSD test at $\mathrm{P}<0.05$.

\section{RESULTS AND DISSCUSSION}

\section{Field Study}

Effects of starter $\mathrm{N}$ fertilizer and rhizobia inoculant on lentil grain yield at two locations in 2012 are shown in Table 2. At CARC, which had the previous history of lentil, yield was 1216 (averaged over all treatments) which is slightly lower than the yield obtained from SG farm $\left(1420 \mathrm{~kg} \mathrm{ha}^{-1}\right)$. It could be due to variation in soil characteristics as well as higher pressure of pest at CARC due to previous history of the crop in that land. Neither rhizobia inoculant, nor starter $\mathrm{N}$ showed significant influence on lentil grain yield. Application of rhizobia inoculant increased lentil grain yield slightly which was not statistically significant at $\mathrm{P}=0.05$ level. It seems that in this rain-fed system, lentil yield was mostly limited by moisture availability rather than nutrient availability. Therefore, soil $\mathrm{N}$ content was sufficient to support moisture- limited growth and development of lentil and extra $\mathrm{N}$ did not contribute to any further boost of yield. 


\section{Greenhouse Study}

Some characteristics of lentil plants responded to the experimental treatments in the greenhouse study (Table 3 and Table 4). Treating seeds with rhizobium significantly increased root length (from 18 to $20 \mathrm{~cm}$ ), nodule number on plant root (from 0.93 to 2.49 nodule plant-1), and plant biomass (from 182 to $228 \mathrm{mg}$ ) at full bloom stage (Table 3). Except protein content, which responded positively to the application of starter $\mathrm{N}$, other variables did not respond to $\mathrm{N}$ application. However, not a significant difference was found among the fertilizers in this regard.

Neither yield nor yield components were affected by rhizobium inoculation or starter $\mathrm{N}$ (Table 4). However, grain protein responded significantly to the experimental treatments. Application of rhizobium inoculant significantly enhanced grain protein content at harvest. Grain protein in non-inoculated crops was $26.7 \%$, whereas grains of rhizobium-inoculated crops contained $28.9 \%$ protein. Application of starter $\mathrm{N}$ was also associated with higher protein content in grains and straws. In the absence of rhizobium inoculant, the greatest protein content was obtained from urea treatment $(28.1 \%)$ whereas in the presence of rhizobium inoculant, U+ESN produced the highest protein content (30.9\%). Compared to the control, application of rhizobium plus U+ESN enhanced protein content by about $34 \%$ which is very notable. The protein content in pulse crops highly affects their food and feed 
utilizations. Lentil has long been recognized as an excellent source of protein in the human diet and livestock consumption and increment in their protein content can increase their marketability. However, since nitrogen management did not influence yield, its effect on protein may not be economically justified yet. Moreover, although the application of U+ESN fertilizer significantly magnifies protein content, the soil residual $\mathrm{NO}_{3}-\mathrm{N}$ in this treatment was also very high which will be highly prone to leaching in the shallow soil and polluting the ground water resources.

More efforts are needed to enhance yield and protein simultaneously while considering the environmental protection.

\section{CONCLUSION}

The results of the current study indicated that lentil did not respond appreciably to $\mathrm{N}$ management (rhizobia inoculation and application of starter N). Both of these treatments, however, enhanced grain protein concentration. More efforts are needed to enhance yield and protein simultaneously while considering the environmental protection. 


\section{REFERENCES}

Alvey, S., C.H. Yang, A. Buerkert, and D.E. Crowley. 2003. Cereal/legume rotation effects on rhizosphere bacterial community structure in West African soils. Biology and Fertility of Soils 37:73-82.

Buhler, D.D., K.A. Kohler, and R.L. Thompson. 2001. Weed seed bank dynamics during a five-year crop rotation. Weed Technology. 15:170-176. doi:10.1614/0890-037X(2001)015[0170:WSBDDA]2.0.CO;2

Chen, C., K. Neill, M. Burgess, and A. Bekkerman. 2012. Agronomic benefits and economic potential of introducing fall-seeded pea and lentil into conventional wheat-based crop rotations. Agronomy Journal . 104:215-224. doi:10.2134/agronj2011.0126

Gan, Y., Hanson, K. G., Zentner, R. P., Selles, F., \& McDonald, C. L. (2005). Response of lentil to microbial inoculation and low rates of fertilization in the semiarid Canadian prairies. Canadian Journal of Plant Science . 85, 847-855.

Frederic, L.H., 1963. Elementary Analysis and the Origins of Physiological Chemistry. Isis, 54, 50-81.

Graham, P. H. and Chatel, D. L. 1983. Agronomy. In W. J. Broughton, ed. Nitrogen Fixation. Vol. 3. Legumes. Pages 556-98. Claredon Press, Oxford, UK.

Haque, I., and N.Z. Lupwayi. 2000. Nitrogen fixation by annual forage legumes and its 
contribution to succeeding wheat in the Ethiopian highlands. Journal of Plant Nutrition 23:963-977. doi:10.1080/01904160009382074

Huang, J., Keshavarz Afshar, R., and Chen, C., 2016. Efficacy of starter nitrogen fertilizer and rhizobia inoculant in dry pea production. Journal of Plant Nutrition and Soil Science Accepted

Herridge, D.F., M.B. Peoples, and R.M. Boddey. 2008. Global inputs of biological nitrogen fixation in agricultural systems. Plant and Soil 311:1-18. doi:10.1007/s11104-008-9668-3

Holl, F. B., and Vose, J. R. 1980. Carbohydrate and protein accumulation in the developing field pea seed. Canadian Journal of Plant Science 60: 1109-1114.

Ito, D., Keshavarz Afshar, R., Chen, C., Miller, P., Kephart, K., McVay, K., Lamb, P., Miller, J., Bohannon, B. and Knox, M. 2015. Multi-environmental evaluation of dry pea and lentil cultivars in Montana using AMMI model. Crop Sci. DOI: 10.2135/cropsci2015.01.0032.

McKenzie, R. H., Middleton, A. B., Solberg, E. D., DeMulder, J., Flore, N., Clayton, G. W. and

Bremer, E. 2001. Response of pea to rhizobia inoculation and starter nitrogen in Alberta. Canadian Journal of Plant Science. 81: 637-643.

Miller, P.R., B.G. McConkey, G.W. Clayton, S.A. Brandt, J.A. Staricka, A.M. Johnston, G.P. Lafond, B.G. Schatz, D.D. Baltensperger, and K.E. Neill. 2002. Pulse crop adaptation 
in the northern Great Plains. Agronomy Journal . 94:261-272.

doi:10.2134/agronj2002.0261

Montana Agricultural Statistics. 2014. [Online] Available:

http://www.nass.usda.gov/Statistics by_State/Montana/Publications/Annual Statistic

al_Bulletin/2014/Montana_Annual_Bulletin_2014.pdf

Salvagiotti, F., Cassman, K. G., Specht, J. E., Walters, D. T., Weiss, A. and Dobermann, A.

2008. Nitrogen uptake, fixation and response to fertilizer $\mathrm{N}$ in soybeans: $\mathrm{A}$ review. Field Crops Research. 108: 1-13.

Van Kessel, C., and Hartley, C. 2000. Agricultural management of grain legumes: has it led to an increase in nitrogen fixation?. Field Crops Research. 65: 165-181.

Yunusa, I.A.M., and M.A. Rashid. 2007. Productivity and rotational benefits of grass, medic pastures and faba beans in a rainfall limited environment. Soil Tillage Soil Tillage Research. 97:150-161. doi:10.1016/j.still.2007.09.013

Zakeri, H., \& Bueckert, R. (2015). Post-flowering biomass and nitrogen accumulation of lentil substantially contributes to pod production. Crop Science, 55(1), 411-419. 
Table 1. Soil characteristics at the experimental sites.

\begin{tabular}{|c|c|c|c|c|c|c|}
\hline \multirow[t]{2}{*}{ Year } & \multirow[t]{2}{*}{ Sites } & \multirow[t]{2}{*}{$\mathrm{pH}$} & \multirow{2}{*}{$\begin{array}{l}\text { Organic matter } \\
\mathrm{g} \mathrm{kg}^{-1}\end{array}$} & \multicolumn{2}{|c|}{$\mathrm{NO}_{3}-\mathrm{N}\left(\mathrm{mg} \mathrm{kg}^{-1}\right)$} & \multirow{2}{*}{$\begin{array}{l}\text { Olsen-P } \\
\mathrm{mg} \mathrm{kg}^{-1}\end{array}$} \\
\hline & & & & $0-0.15 \mathrm{~m}$ & $0.15-0.30 \mathrm{~m}$ & \\
\hline 2012 & CARC & 6.9 & 5.1 & 4.5 & 8.5 & 15 \\
\hline & SG farm & 6.8 & 4.0 & 8.0 & 9.0 & \\
\hline 2015 & EARC & 8.3 & 2.3 & 6.5 & - & 26 \\
\hline
\end{tabular}


Table 2: Effect of rhizobia inoculant and starter $\mathrm{N}$ on lentil at two location in central Montana in 2012.

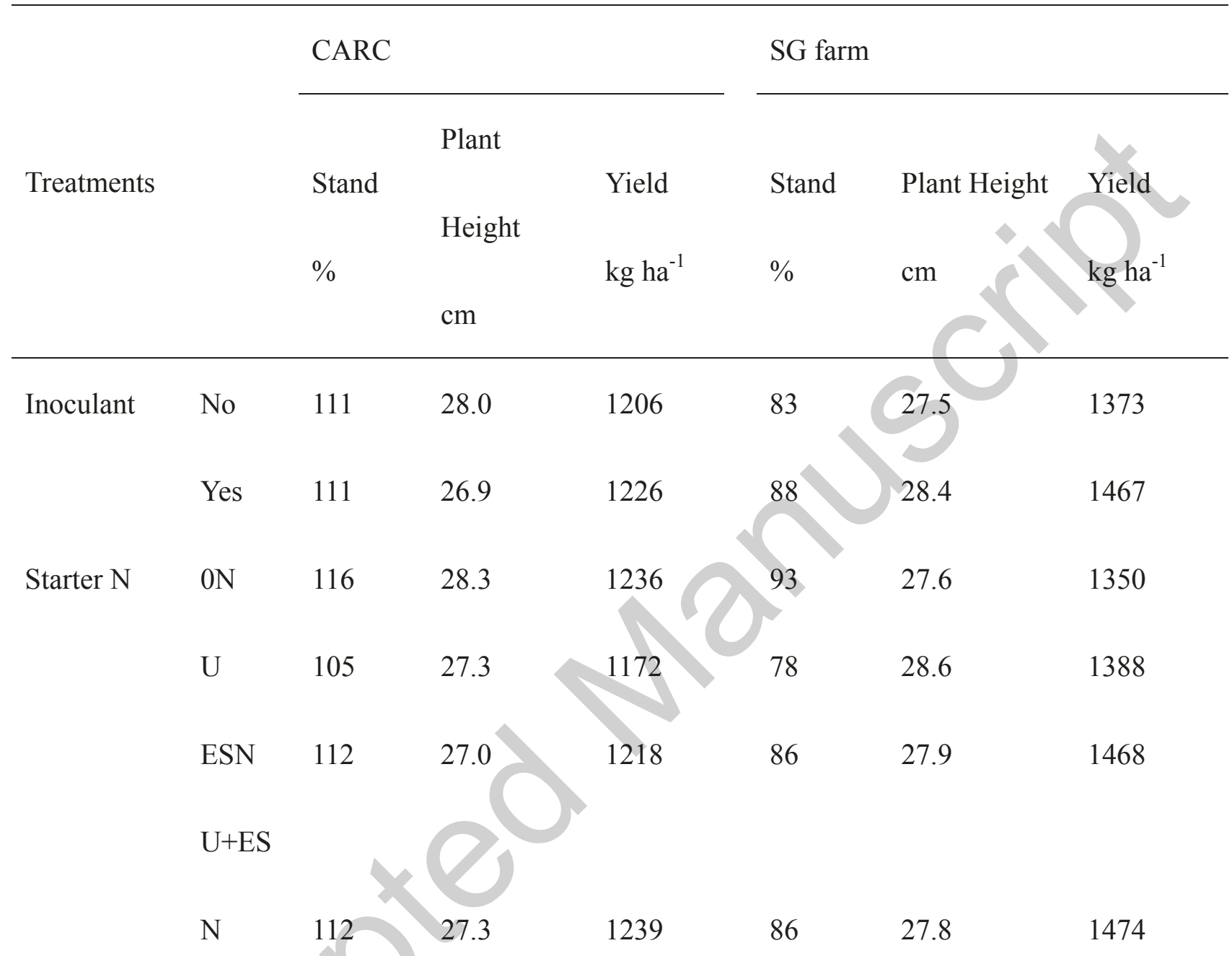

Interaction

No

$\begin{array}{rrrrrrr}\text { inoculant } \quad \text { ON } & 106 & 29.3 & 1247 & 86 & 26.5 & 1278 \\ & & & & & & 1292 \\ \mathrm{U} & 110 & 27.0 & 1110 & 77 & 28.5 & \\ \text { ESN } & 104 & 28.5 & 1259 & 84 & 26.5 & 1474\end{array}$




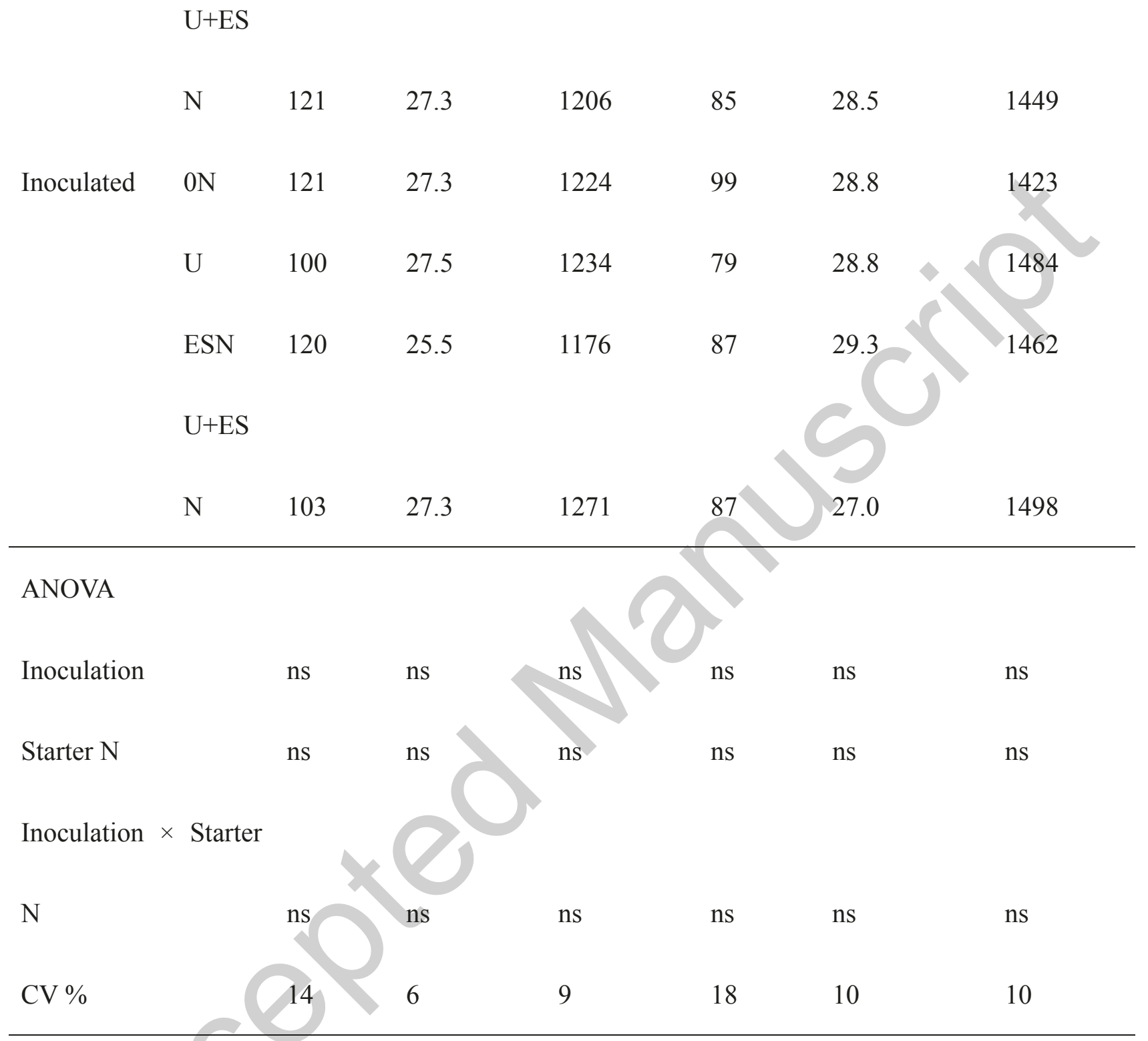

ns, not significant at $\mathrm{P} \leq 0.05$.

$\mathrm{U}: 22 \mathrm{~kg} \mathrm{Nha}^{-1}$ in the form of urea

ESN: $22 \mathrm{~kg} \mathrm{~N} \mathrm{ha}^{-1}$ in the form of ESN (slow release nitrogen). 
Table 3: Lentil characteristics at seedling stage (7-leaf stage) and full bloom stage as influenced by rhizobium inoculation and application of starter $\mathrm{N}$ at the greenhouse study.

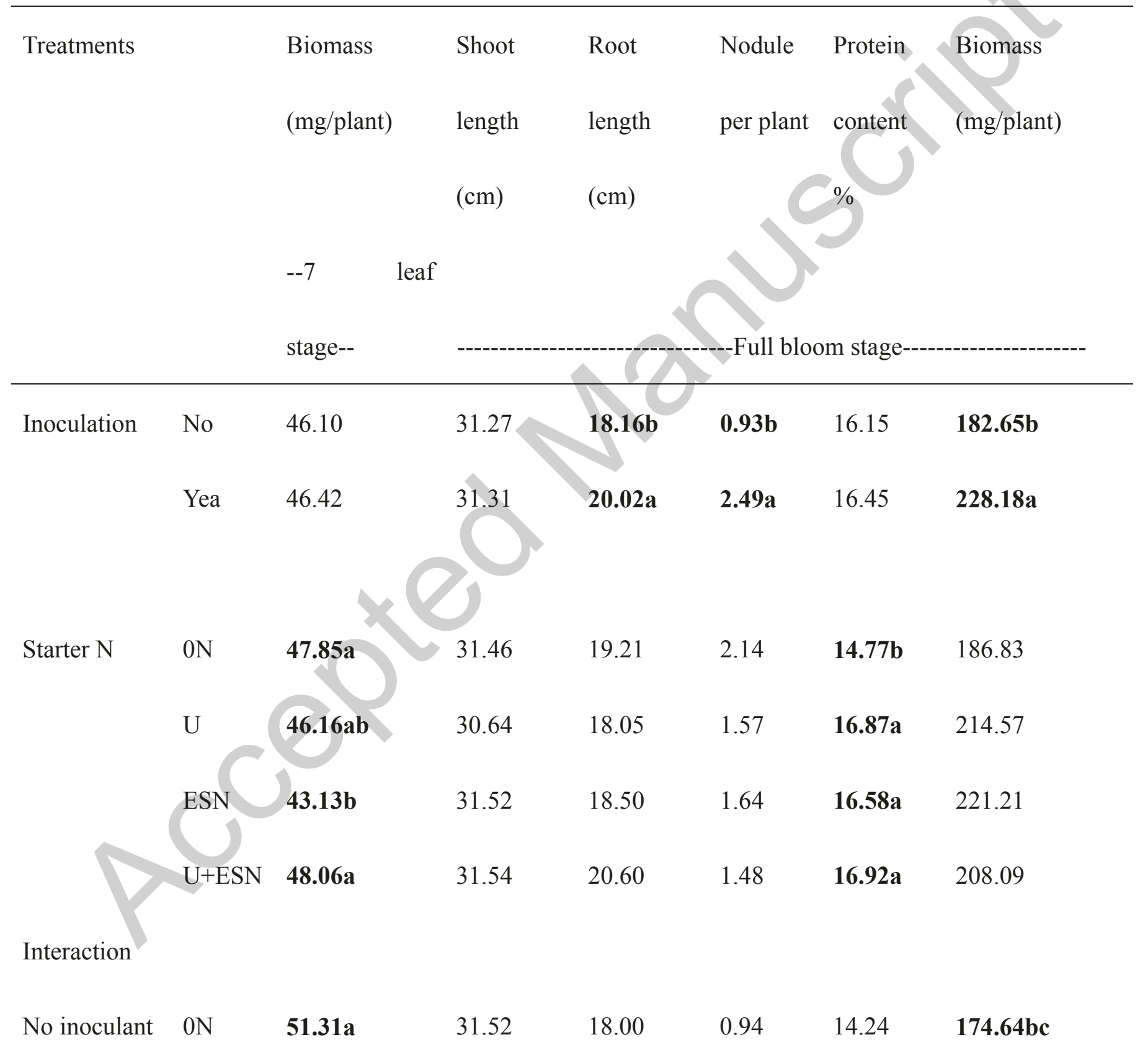




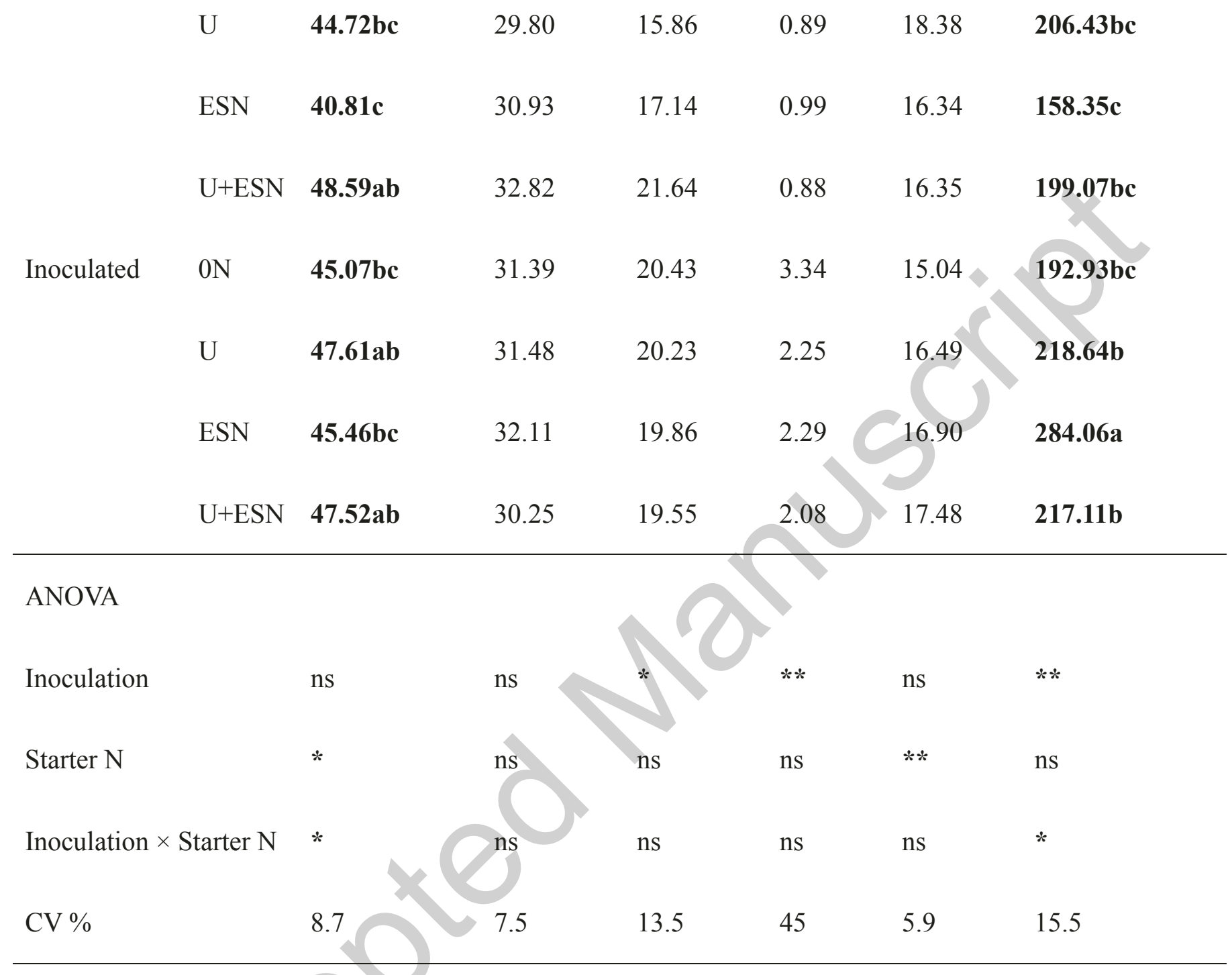

$* \mathrm{P} \leq 0.05 ; * * \mathrm{P} \leq 0.01 ; \mathrm{ns}$, not significant at $\mathrm{P} \leq 0.05$.

Means are separated using LSD test at $\mathrm{P}<0.05$.

$\mathrm{U}: 22 \mathrm{~kg} \mathrm{Nha}^{-1}$ in the form of urea

ESN: $22 \mathrm{~kg} \mathrm{~N} \mathrm{ha}^{-1}$ in the form of ESN (slow release nitrogen). 
Table 4: Lentil characteristics at maturity stage as influenced by rhizobium inoculation and application of starter $\mathrm{N}$ at the greenhouse study.

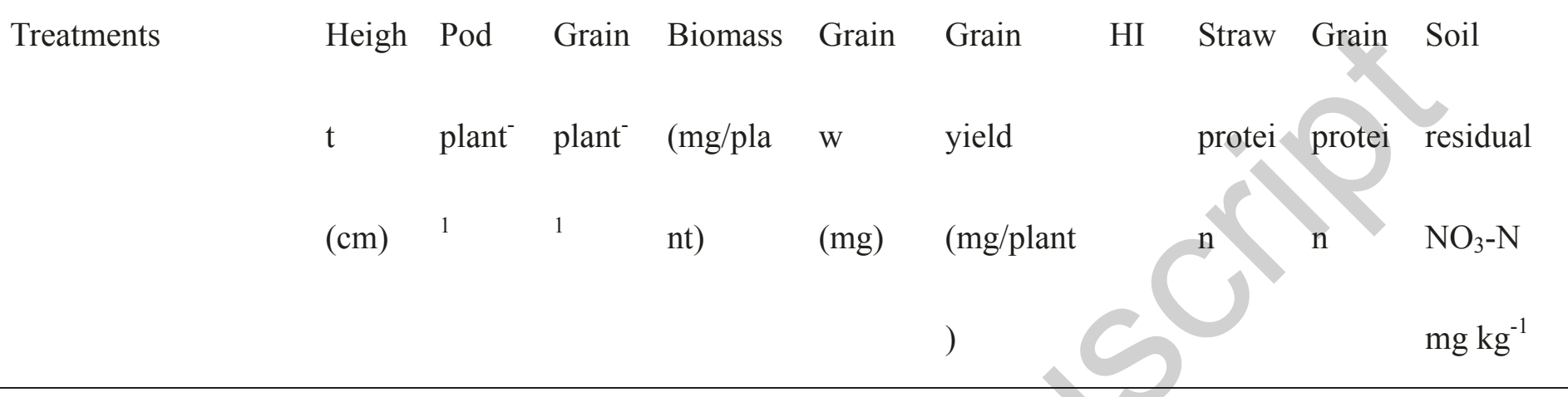

Inoculatio

$\begin{array}{llllllllllll}\text { No } & 33.4 \mathbf{a} & 4.4 & 4.1 & 426 & 44 & 180 & & 9.1 & \mathbf{2 6 . 7 b} & 6.4\end{array}$

$\mathrm{n}$

$\begin{array}{lllllllllll}\text { Yea } & \mathbf{3 1 . 7 b} & 4.5 & 4.1 & 413 & 44 & 182 & & 8.9 & \mathbf{2 8 . 9 a} & 5.7\end{array}$

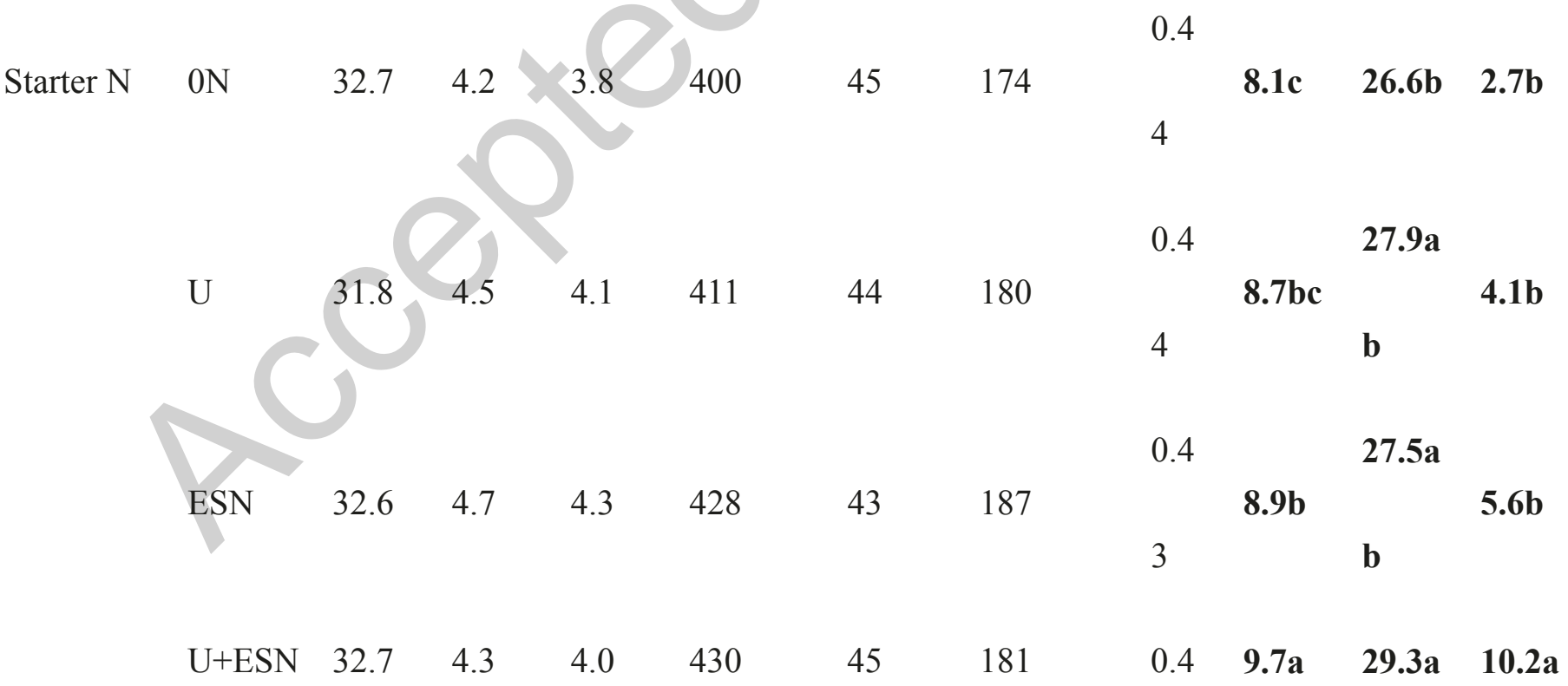


Interaction

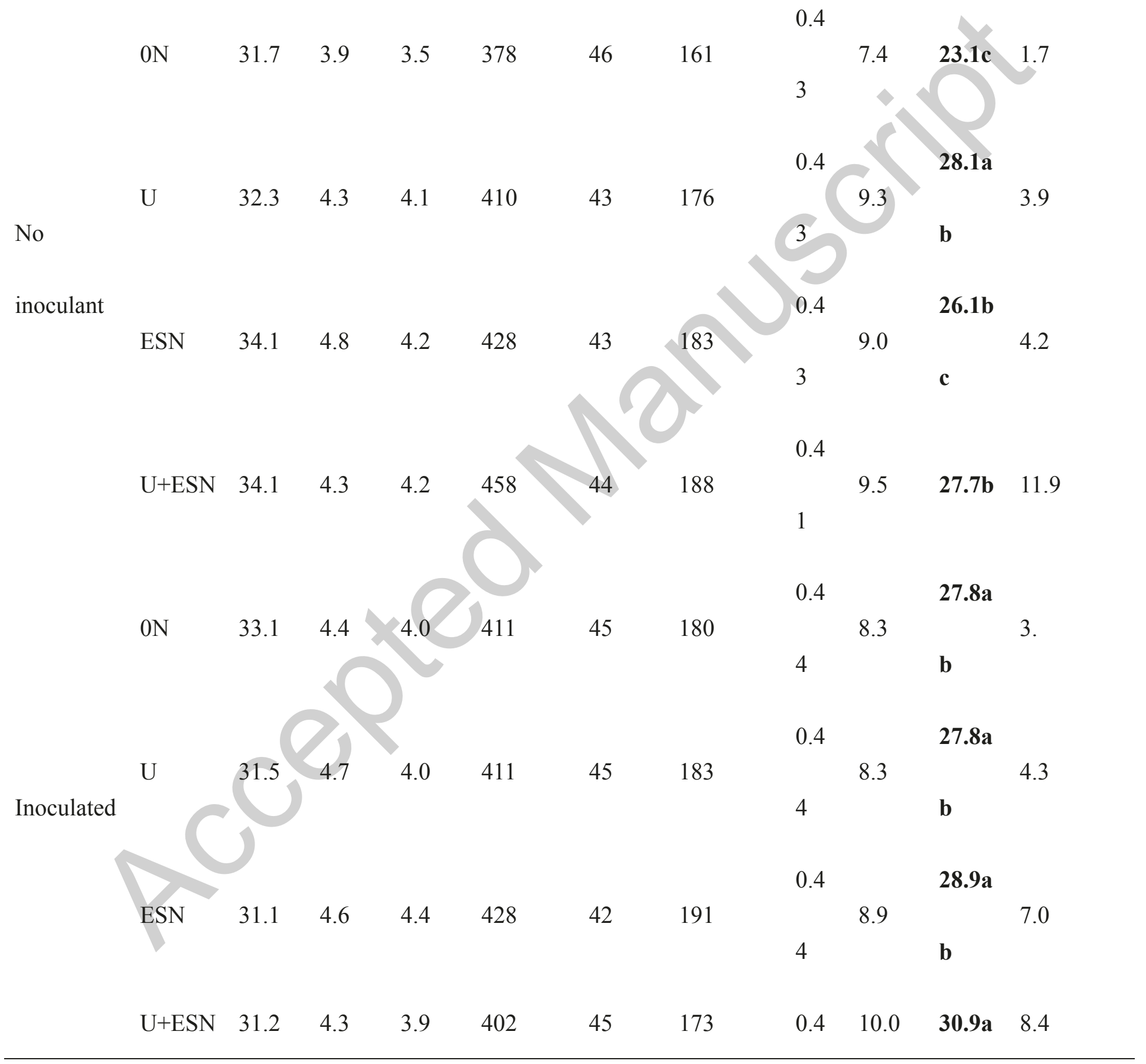


3

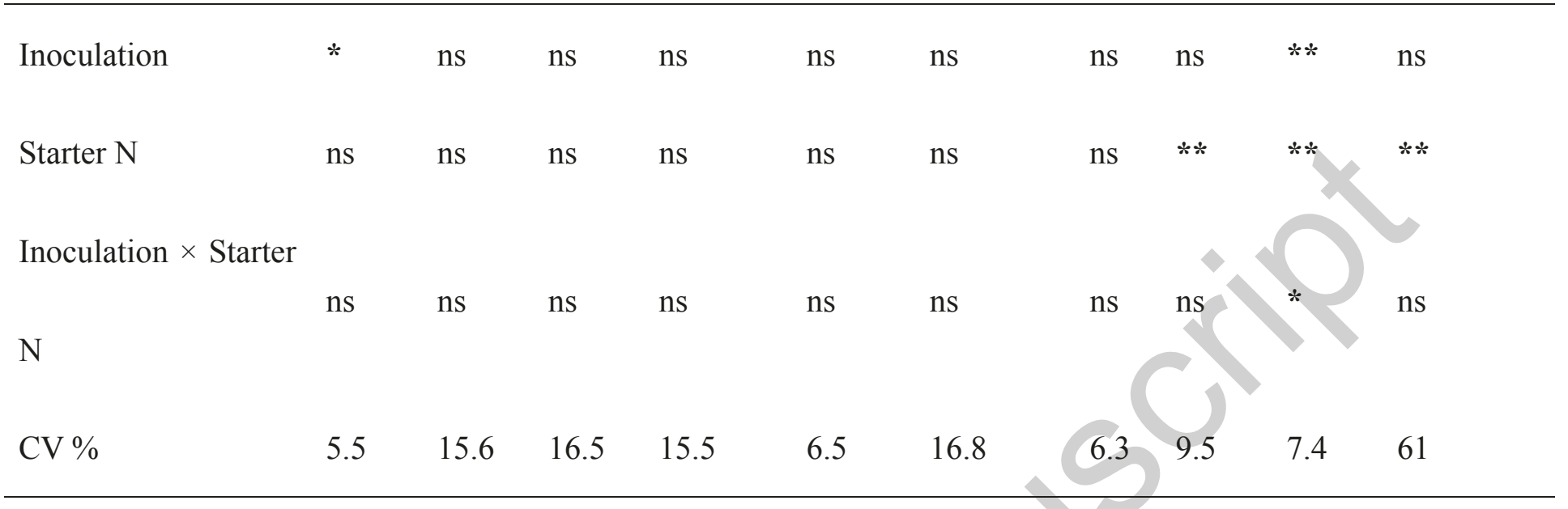

$* \mathrm{P} \leq 0.05 ; * * \mathrm{P} \leq 0.01 ; \mathrm{ns}$, not significant at $\mathrm{P} \leq 0.05$.

Means are separated using LSD test at $\mathrm{P}<0.05$.

$\mathrm{U}: 22 \mathrm{~kg} \mathrm{~N} \mathrm{ha}^{-1}$ in the form of urea

ESN: $22 \mathrm{~kg} \mathrm{~N} \mathrm{ha}^{-1}$ in the form of ESN (slow release nitrogen). 

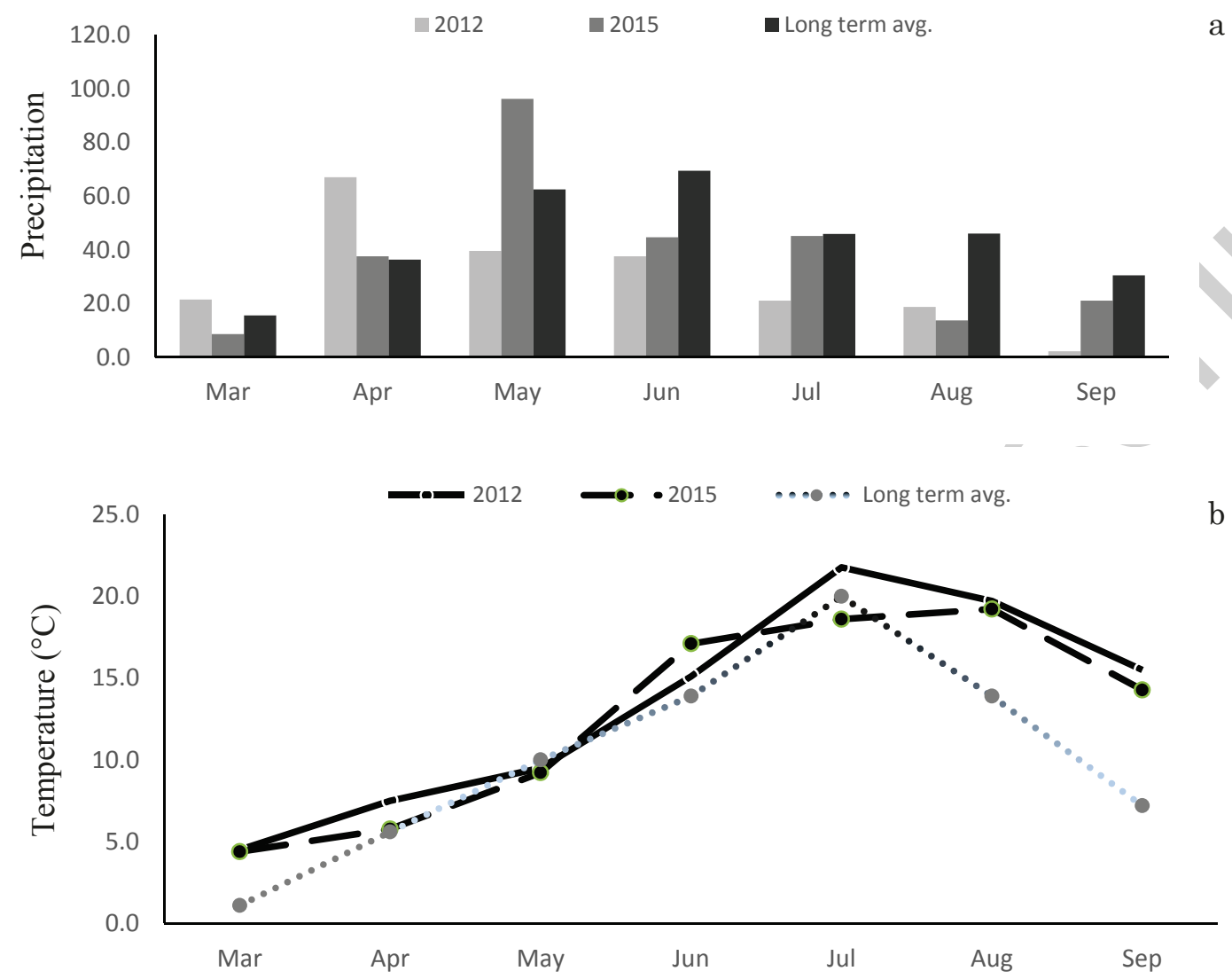

Fig.1. Cumulative monthly precipitation (a) and average monthly air temperature (b) in 2012 and 2015 in central Montana along with their long-term averages. 